\title{
クロムエ場従事者にみられた多発性肺癌
}

\section{Multiple Bronchogenic Carcinoma in Chromate Workers}

大崎 饒・阿部庄作・常田育宏・木村清延 · 三上 洋 · 村尾 誠

抄録：1クロム工場従業員よりの3 例の多発性肺癌一両側性一を経験した。内， 2 例は両肺に 生じた扁平上皮癌例であり，1例は左肺に小細胞癌，右肺に扁平上皮癌の同時発生例で あった。扁平上皮癌両側発生例の内 1 例は手術を行った。1例は生前に診断を得たが病 期が進行していたため死亡し、最後の例と共に剖検により子細に検索し得た。

昭和56年春までにク口ム工場従事者303名中, 21例の肺癌を見出し, この内, 剖検, 手術 の可能な例 8 例であった。肺癌発生率の高頻度，また症例のような多発性肺癌を生ずる ことょりクロム塩類の強力な発癌性が示唆された。

\section{はじめに}

近年，肺癌症例の増加が注目されるようにな り，喫煙を始めとする種々発癌性物質の吸入に ついて注意が喚起されている．肺癌例の気管支 を子細に検索すると主病変の他に, いくつかの 癌病変を証明し得るいわゆる多発性癌もみられ る機会が多くなってきた。一般住民におけるこ のような多発性肺癌の頻度が多くなってきたこ とより, 強力な発癌性を有する物質の吸入によ って生じると考えられる肺癌ではこのような多 発性例も当然多くなることが予想される。
われわれは1972年より某クロム工場従業員の 肺癌発生について追究し1981年春までに21例の 症例を発見している。この内，病理学的検索の し得た例は 8 症例で (剖検 3 例, 手術 5 例), こ の内, 3 例に両側肺発生のいわゆる多発癌をみ たことはクロム化合物の強力な発癌性を示唆す るものと考える。

\section{1)症例提示}

全症例男性であり，内 1 例は手術を行い, 残 ク.2 例は剖検で確認した(Table. 1)

Table 1. Patient's profile, site and cell type of bilateral bronchogenic carcinoma

\begin{tabular}{cccccccc}
\hline Case & Age & Sex & $\begin{array}{c}\text { Working history as } \\
\text { a chromate worker }\end{array}$ & $\begin{array}{c}\text { Smoking history } \\
\text { pack years }\end{array}$ & \multicolumn{2}{c}{$\begin{array}{c}\text { Site and cell type } \\
\text { right lung left lung }\end{array}$} & Confirmation \\
\hline 1 & 45 & male & 14 years & 25 & $\begin{array}{c}\text { squamous } \text { squamous } \\
\text { cell ca. }\end{array}$ & Surgery ca. \\
2 & 49 & male & 26 years & 38 & $\begin{array}{c}\text { squamous squamous } \\
\text { cell ca. cell ca. }\end{array}$ & Autopsy \\
3 & 67 & male & 10 years & 37 & $\begin{array}{c}\text { squamous small } \\
\text { cell ca. cell ca. }\end{array}$ & Autopsy \\
\hline
\end{tabular}


Fig. 1. P-A radiograph of case No. 1

An abnormal shadow was seen in the right upper lung field near the hilum. No abnormal shadow was seen in the left lung.

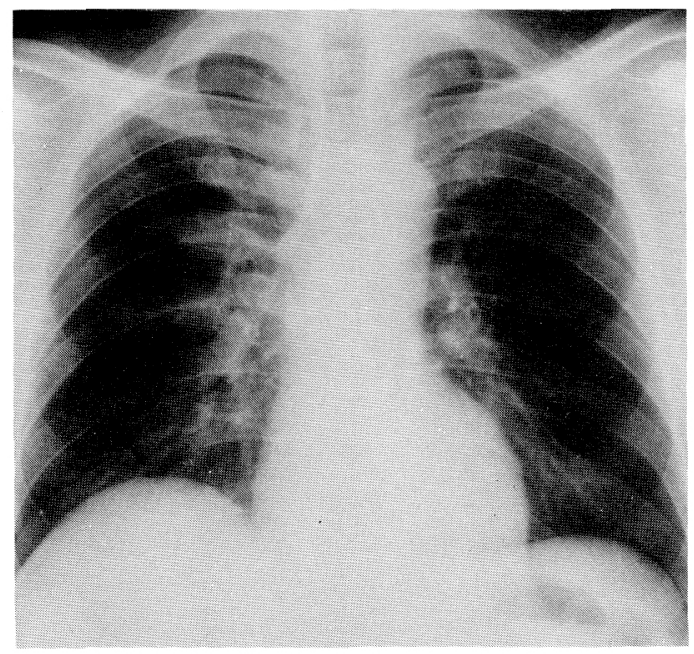

（症例 1）45才男性，1980年春のク口ム従業員 に対する肺癌集団検診で胸部異常陰影を発見さ れた。呼吸器症状は全く無い。精査のため北大 第 1 内科に入院した。喀痰細胞診で扁平上皮癌 細胞を検出した。

胸部平面写真 (Fig.1) で右上肺野肺門寄りに異 常㓌影が認められる。左肺には異常陰影はない。 平面断層写真 (Fig.2)で $2 \times 4 \mathrm{~cm}$ の辺縁不整の卯 円形腫瘤影が認められる。

気管支鏡検査では右肺上葉のB.2に経度狭窄像 を見るだけで粘膜には異常はなかった。

左肺では下葉のB.8の入口部に表面微細粒状の 結節性腫瘤を認め(Fig.3), 同部の擦過細胞診で 扁平上皮癌と診断し手術を行った。始め右肺の 上葉摘出を施行し，1 月月後に左下葉を切除し た。右肺の腫瘍は大きさは $3 \times 2.5 \times 2 \mathrm{~cm}$ で気管 支との交通は明らかでなく，B.2を圧排するよう な未梢発生の病変であった (Fig.4). 組織学的に は軽度角化傾向を示す扁平上皮癌 (Fig.5) で, 右 肺門，縦隔リンパ節には転移を認めなかった。

左肺はB.8開口部に存在する約 $3 \times 4 \mathrm{~mm}$ の表 面不整のポリープ状の小腫瘤(Fig.4)で, 組織学 的には癌細胞侵潤が気管支壁内に限局する扁平 上皮癌の早期のものであった(Fig.5). 左肺門リン
Fig. 2. Tomogram of case No. 1

Oval tumor with a irregular contour was seen in the right upper lung field.
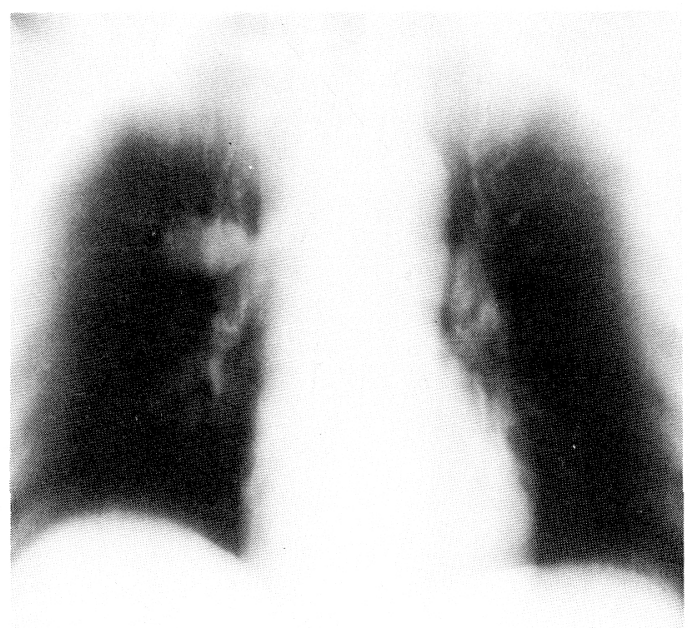

Fig. 3. Bronchoscopic finding of the left lung. A polyp-like prominence with irregular surface was present at the base of the anterior segmental bronchus.

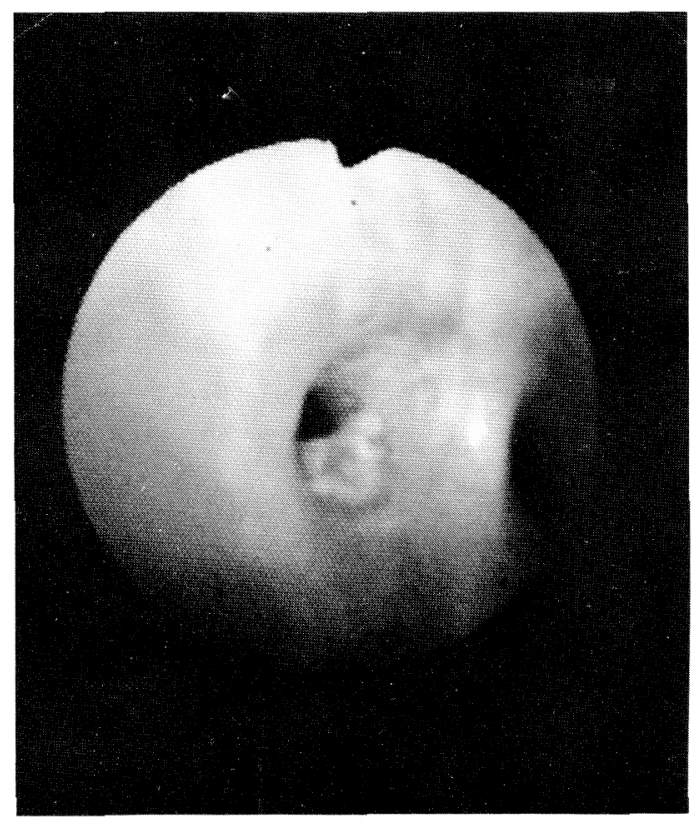

パ節への癌転移は認めなかった。

（症例 2 ）49才男性, 昭和48年10月頃, 咳嗽, 喀痰, 発熱が出現し, 感冒として治療を受けて, 
Fig. 4. Surgical specimen of case No. 1

Left, Tumor formation in the posterior segment of the right upper lobe.

Right, Small prominence with irregular surface at the base of the anterior segmental bronchus of the left lower lung.
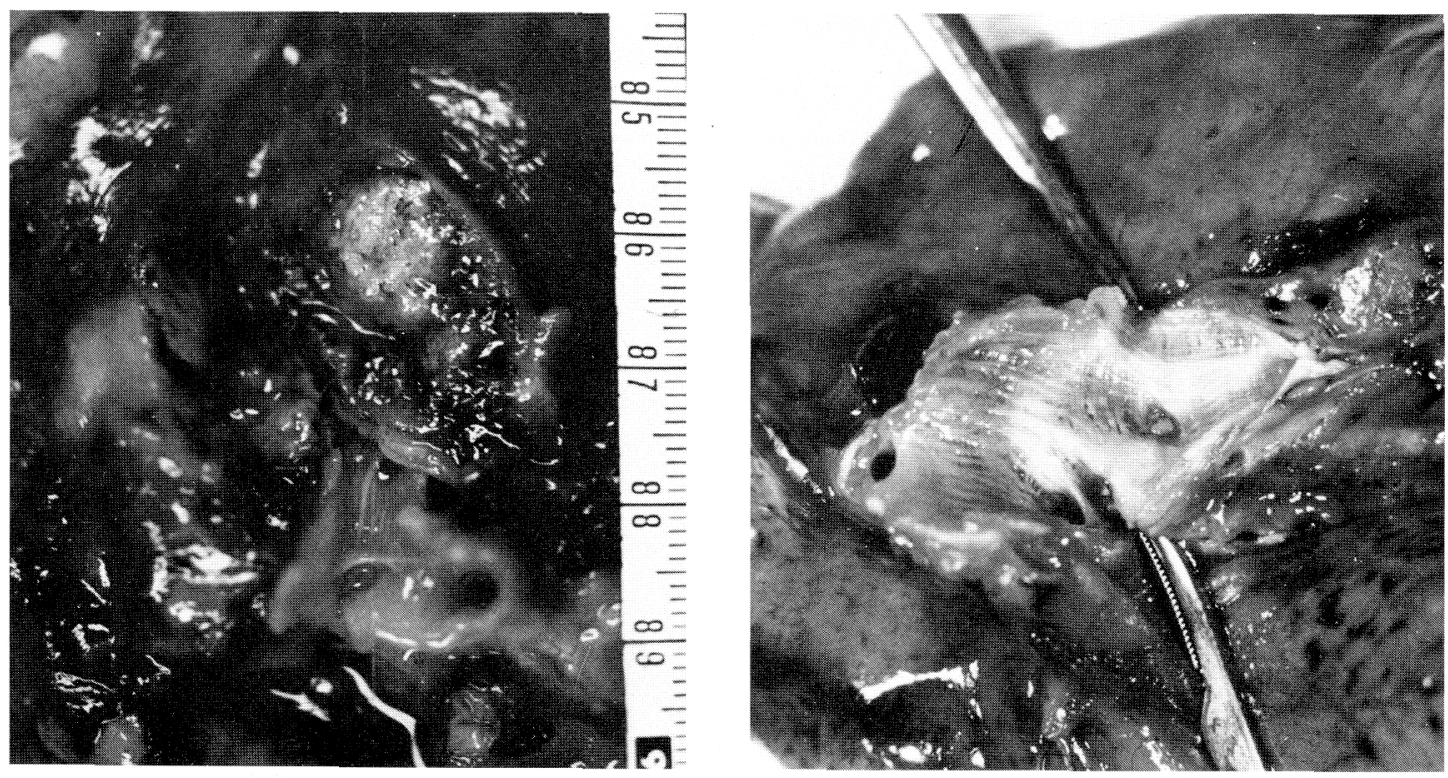

Fig. 5. Microscopic findings of case No, 1

Left, Well developed squamous cell carcinoma of the right lung (Hematoxylin-Eosin 400X).

Right, Squamous cell carcinoma confined to the mucus layer of the bronchus of the left lower lobe (Hematoxylen-Eosin 400X).

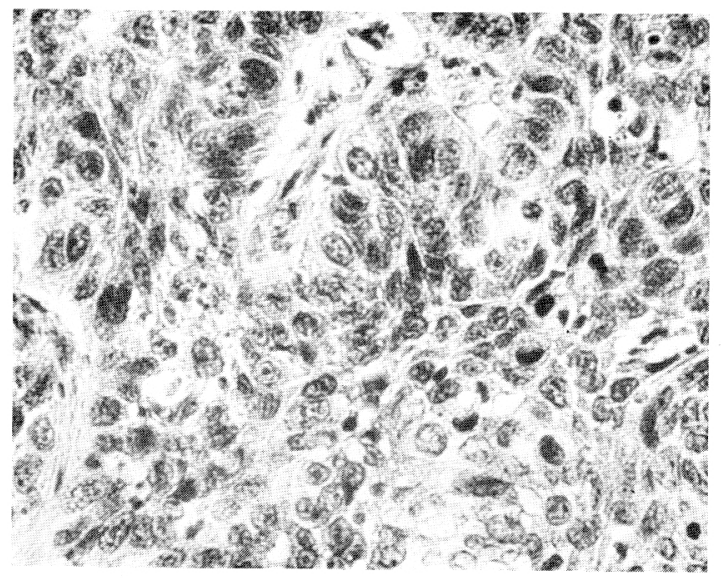

一時軽快したが同様の症状が続いた。胸部写真

で異常院影を発見され，精查，治療のため当科

に入院した。

胸部写真 (Fig.6)では左肺門部の腫瘤院影と,

それに連続する下肺野の異常影が認められる。

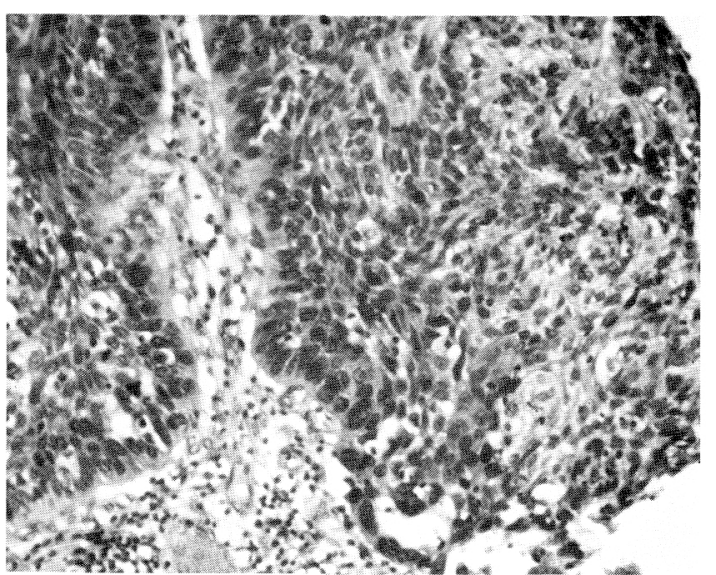

右肺には異常㓌影は認められない。

気管支鏡検査では，左肺は下葉支起始部に内 腔をほ心゙完全に閉塞する表面不整の隆起性変化 を認めた (Fig.7). 右肺では上葉支のB.2入口部に 晹出血性のポリープ状腫瘤を証明した(F1g.7). 
Fig. 6. Plain radiograph of case No. 2 Abnormal shadow was present in the left mid-lung field and left hilum.

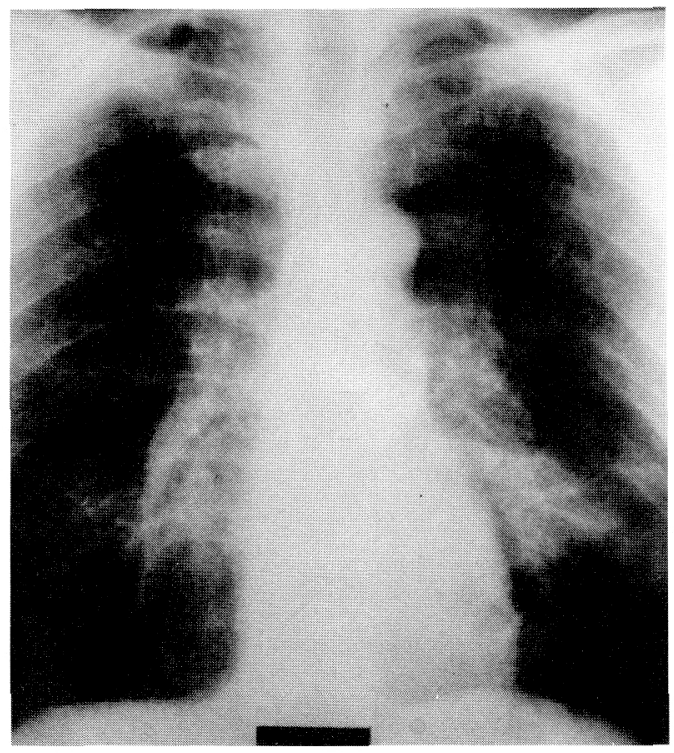

これら左右の病変は気管支鏡下生検に上り扁平 上皮癌と診断した(Fig.8). 手術不能のため化学 療法を行ったが，左腫瘤は次第に増大し左側肺 は完全無気肺となり，1 年 2 ケ月後に死亡した。 剖検では左肺は下幹を中心として腫瘤を認め, 侵潤は左主気管支に及んでいた。右肺は B. 2 基 部を中心の腫瘤形成であり細胞侵潤は気管支周 井に及んでいた。右肺門リンパ節への転移はみ られなかった。

（症例 3 ）67才男性, 手足の疼痛，しびれ感市 るいは腹痛など多彩な症状で某病院に長期療着 中であったが，昭和 48 年 9 月頃より，愘痰，咳 嗽が出現してきた。

胸部写真(Fig.9)で左肺門部腫瘤と胸水貯留を 認めた。右肺には異常影はなかった。病状悪化 し，6ヶ月後に某病院で死亡した。

剖検により左肺は上幹部原発と考えられる小 細胞癌(Fig.10)であり，右下葉のB.10入口部にも 侵潤が気管支周囲に及ぶ扁平上皮癌(Fig.10)を 認めた。左肺門リンパ節に癌転移を証明したが,

Fig. 7. Bronchoscopic findings of case No. 2

Left, Tumor formation with an irregular surface occluded the internal lumen of the left lower lobe bronchus almost completely.

Right, Polyp-like tumor with bleeding was present at the base of the posterior segmental bronchus of the right upper lobe.
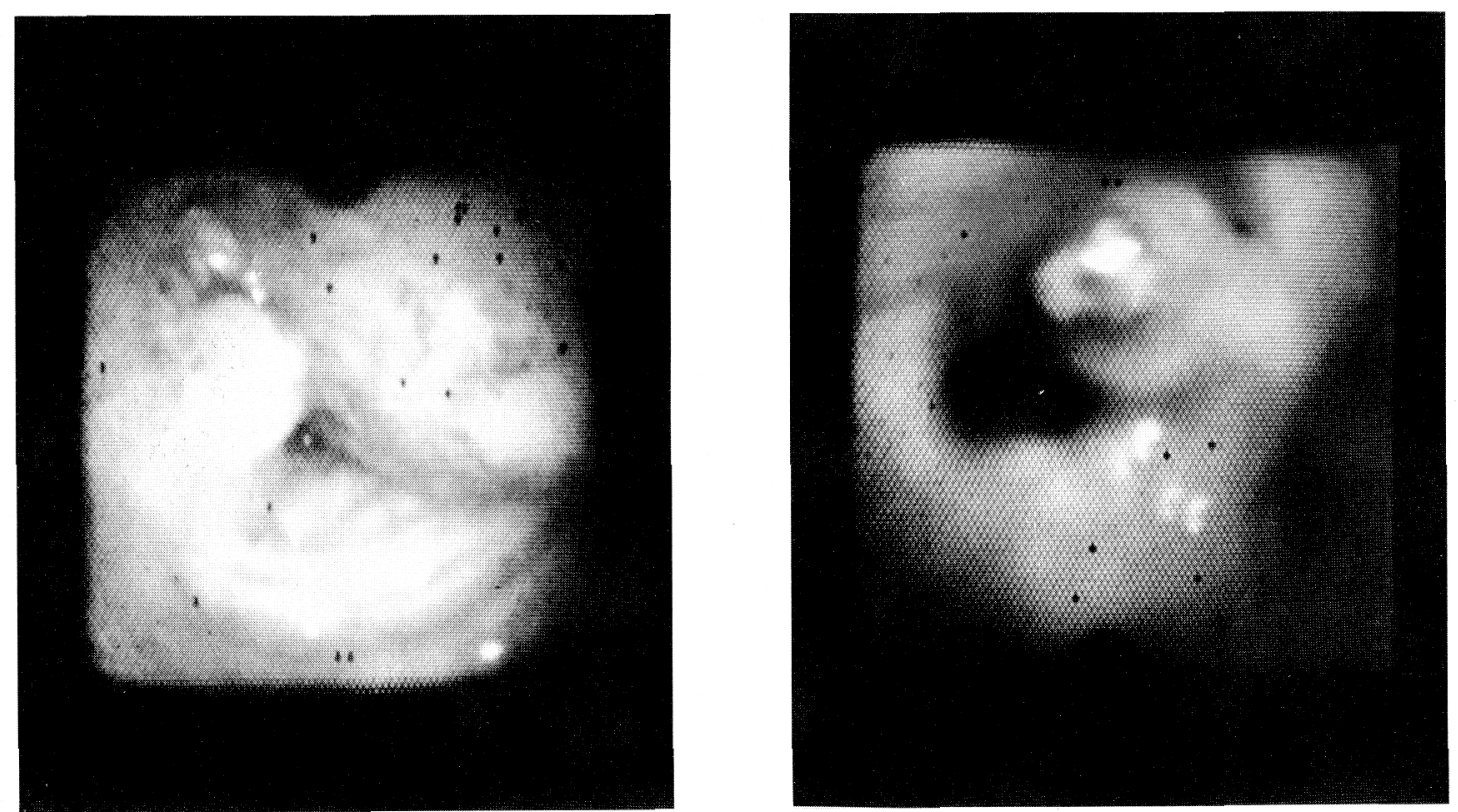
Fig. 8. Microscopic findings of case No. 2

Left, Punch-biopsy specimen of the lesion of the right lung.

-Squamous cell carcinoma-(Hematoxylin-Eosin 100X).

Right, Squamous cell carcinoma of the left lung (Hematoxylin Eosin 400X).
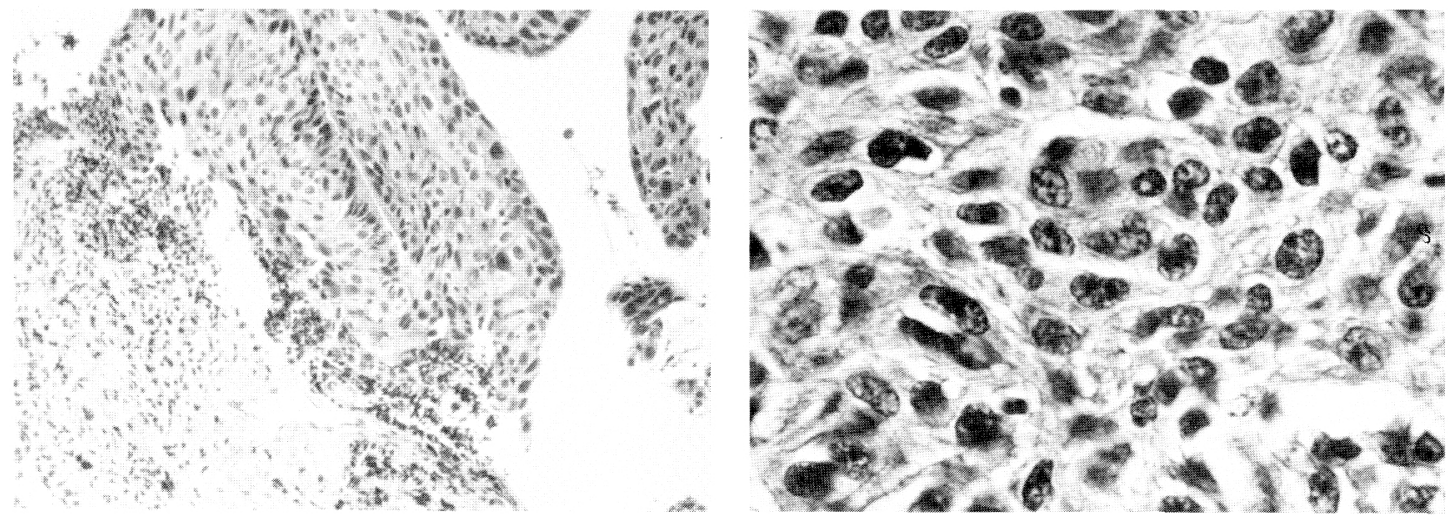

Fig. 9. Routine chest film of case No. 3 Abnormal shadow in the left middle and lower lung fields with pleural effusion.

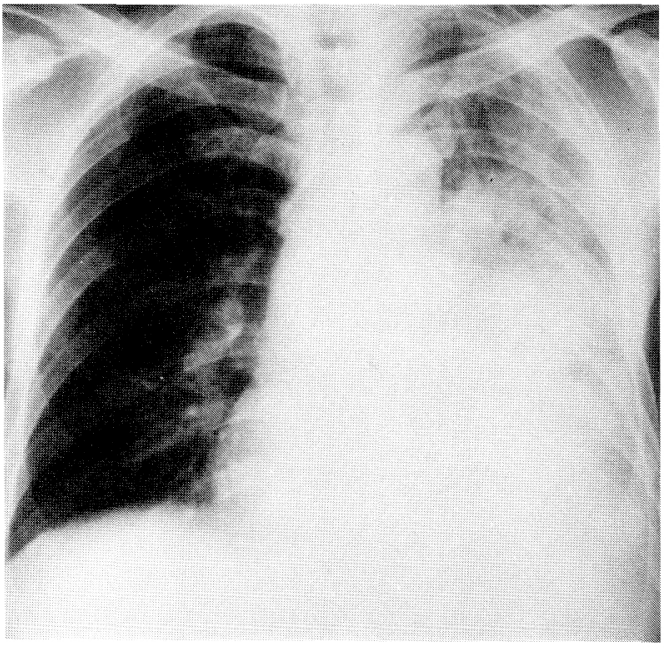

Fig. 10. Pathological specimen of case No. 3

Left, Squamous cell carcinoma of the right lower lobe (Hematoxylin-Eosin 400X).

Right, Small cell carcinoma of the left upper lobe (Hematoxylin-Eosin 400X).
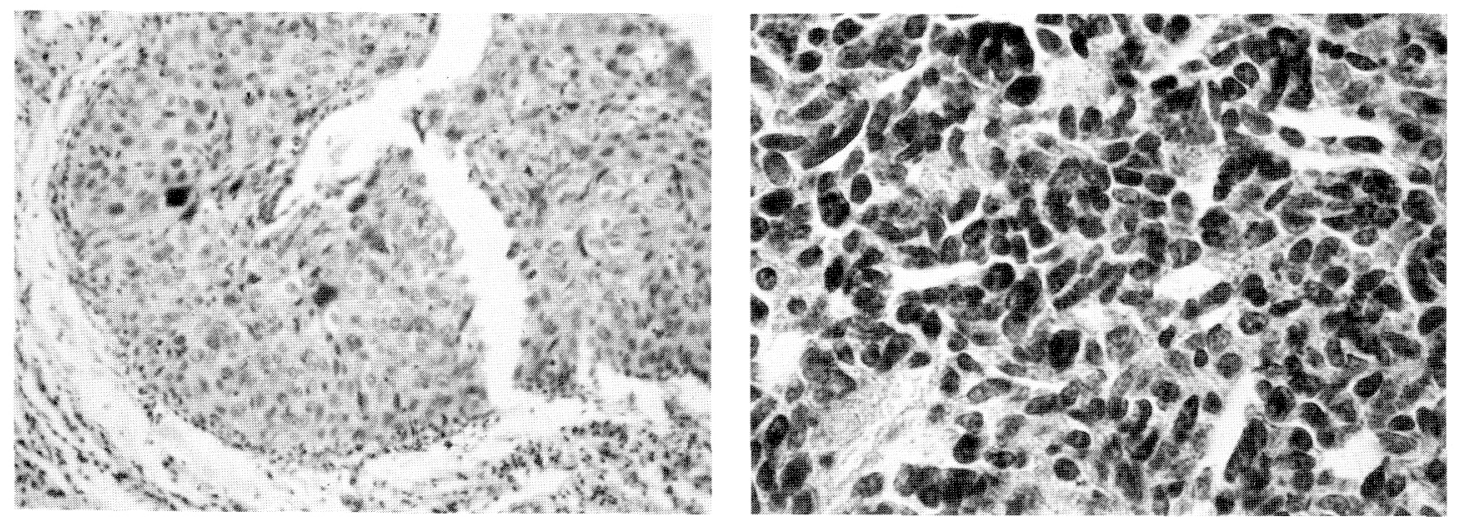
右肺門リンパ節への転移はなかった。また他蔵 器の悪性腫瘍はみられなかった。

\section{2) 考 案}

近年, 一般住民より発生する肺癌症例におい ても, 多発性の癌が認められるようになってき た. Robinson and Jackson ${ }^{1}$ ) は肺癌500例中に 9 例の複原発癌 (dual primary cancer) を発見し，肺の多発性腫瘍はまだ広く認められ ていないが生じ得るものであると報告している。 Hartsock and Fisher ${ }^{2)}$ は1961年に, 両側性肺 癌の報告は僅か26例にすぎないといっている. しかしながらRohwedder and Weatherbeeの 1974年の総説では155例の多発性原発性肺癌を まとめ, このタイプの癌発性が増加しているこ とを指摘している。そして多発性肺癌の発性頻 度を0.2〜1.8\%であると算出した.Auerbachら ${ }^{4)}$ は多発性原発性侵潤肺癌を255肺癌例中 9 例 $(3.5$ \%）に認め，多発肺癌はそんなに頻繁なもので はないが決して稀なものでないことを強調して いる. 最近, この多発性発生が注目されるよう になったため, 気管支の病理学的検索が精細と なり病理学的に診断される例が多くはなってき ているが, 臨床的に診断される例はあまり多く ない. 5)しかしながらファイバー気管支鏡の発達 により，気管支の臨床的検索も子細になってき たため,このような臨床診断例の報告が最近多 くなりつつある。

多発性の肺癌はその発性部位が両肺のこと,2),3),

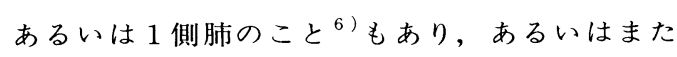
病変が気管支に複数個多発してみられる場合も ある? ), 8 多発性肺癌の際に同時発生または異時 発生 (synchronous and asynchronous) でも同 一組織型としては扁平上皮癌のことが最も多い. 異種の組織型としては扁平上皮癌と小細胞癌の 組み合わせが最も多く, 次いで扁平上皮癌と腺 癌との発生である. ${ }^{3}$ わわわれの例でもこの傾向 を示し 2 例が扁平上皮癌の同一組織型であり， 1 例が扁平上皮癌, 小細胞癌であった。

画側性肺癌の場合に 3 つの可能性がある。す なわち, i) 多発性発性, ii ) 1 側が原発で, 他側 がそれよりの転移, iii)肺以外の臓器の悪性腫瘍 よりの転移, である。一般に肺癌が, 解剖学的
に個別の部より発生している場合, 組織型の異 る場合, 離れた気管支の異常粘膜部位より発生し ている場合などには多原発生のものであると認 められる。われわれの症例の所見はこの基準に 合致する。

クロム化合物, 特に 6 価の化合物は強力な発 癌性を有していると考えられている。ク口ム工 場従業員の肺癌発生率は一般住民のそれと比較 して極めて高值を示している.9)一般住民におい ても近年多発性肺癌の頻度が高くなってきてい ることから, 強い発癌物質の吸引によると考之 られるクロム肺癌で毛当然多発例は考慮され なければならない.われわれは昭和 47 年より昭 和56年春までにクロム工場従業員 (303名)中, 21 名の肺癌例を確認した。手術または剖検により 気管支を精細に検索し得た例はこの内 8 例であ った.クロム肺癌の発生頻度の高いこと, これ ら 8 例中， 3 例に多発性肺癌のみられたことは クロム塩類の発癌性の高いことを示唆している. われわれの症例は高度の契煙歴を有するが, 契 煙のみでは説明できない. 石綿肺 ${ }^{10)}$ 。で毛放射性 物質 ${ }^{11,12)}$ でも，これら発癌性の高い物質の吸入に よって多発性肺癌の報告がみられるように，わ れわれの例もクロム塩類の吸入がこの多発性の 原因になっているものと考える。

\section{むすび}

クロム工場従事者にみられた 3 症例の両側性 多発性肺癌例を報告した。これら症例，および クロム工場従事者中の肺癌発生の高いことはク 口ム塩類の強度の発癌性を示唆するものと考之 る.ク口ム塩素に限らず, 高度の発癌物質によ る肺癌は多発性であり得るので, このような例 では十分気管支を子細に検索する必要がある。 早期の例では手術可能の場合もある.

本論文要旨は第21回日本肺癌学会総会において 発表した。 
1) Robinson, C.L.N. and Jackson, C.A.: Multiple primary cancer of the lung. J.Thoracic Surg., 36:166-173, 1958.

2) Hartsock, R. J. and Fisher, E. R.: Bilateral primary invasive carcinoma of lungs. Dis. chest., $39: 421-424,1961$.

3) Rohwedder, J. J. and Weatherbee, L.: Multiple primary bronchogenic carcinoma with a review of the literature. Am. Rev. Respir. Dis., $109: 435-445,1974$.

4) Auerbach, O., Stout, A. P., Hammond, E. C. and Garfinkel, L.: Multiple primary bronchial carcinoma. Cancer, 20:699-705, 1967.

5) Payne, W. S., Clagett, O. T. and Harrison, E. G.: Surgical management of bilateral malignant lesions of the lung. J. Thoracic and Cardiovas. Surg., $43:$ 279-290, 1962.

6) Newman, W. and Adkins, P. C.: Three primary carcinomas of the lung arising in a left lower lobe with; metastasis of two of the tumors. A case report. J. Thoracic Surg., $35: 474-481,1958$.

7) Mc Grath, E. J., Gall, E. A. and Kessler, D. P.:
Bronchogenic carcinoma, a product of multiple sites of origin. J. Thoracic Surg., 24 : 271-283, 1952 .

8) Suemasu, K., Shimosato, Y. and Ishikawa, S.: Multiple minute cancers of major bronchi, a case report. J. Thoracic and Cardiovas. Surg., 68:664-672, 1974.

9) Ohsaki, Y., Abe, S., Kimura, K., Tsuneta, Y., Mikami, H., and Murao, M.,: Lung cancer in Japanese chromate workers. Thorax 33 : $372-374,1978$.

10) Cardova, J. F., Tesluk, H. and Knudson, K. P.: Asbestosis and carcinoma of the lung. Cancer, $15: 1181-1187,1962$.

11) Beyreuther, H.: Multiplicitat von Carcinomen bei einem Fall von sog "Schneeberger" Lungenkrebs mit Tuberkulose. Virchow Arch Arch. Path. Anat., 250:230-243, 1924.

12) Pinchan, A. and Sikl, H.: Cancer of the lung in miners of Jachymov (Joachimatal) : Report of cases observed in 1922-1930. Amer. J. Cancer, $16: 681-722,1932$. 


\section{Multible Bronchogenic Carcinoma in Chromate Workers}

Yutaka OHSAKI, M.D., Yasuhiro TSUNETA, M.D., Shosaku ABE, M.D., Kiyonobu KIMURA, M.D., Hiroshi MIKAMI, M.D. and Makoto MURAO, M.D.

First Department of Internal Medicine, Faculty of Medicine, Hokkaido University. North 15, West 7, Kitaku, SAPPORO, JAPAN

We experienced three cases of bilateral bronchogenic carcinoma among chromate factory workers. The multiple occurrence was diagnosed clinically in two patients, one of which was confirmed by bilateral surgery and the other by autopsy. The last case was recognized only by autopsy. Cell type was bilateral squamous cell carcinoma in two and a combination of squamous cell and small cell carcinoma in one. Until April 1981, 21 cancer patients were found among 303 chromate workers.

The facts that a high incidence of bronchogenic carcinoma is seen among chromate workers and that these three cases showed multiple occurrence strongly suggest the strong carcinogenicity of chromate compounds. 